ISLLAC

Journal of Intensive Studies on Language, Literature, Art, and Culture

Vol. 1 No. 1 September 2017

\title{
TEXT AS MEDIA, MATERIAL, AND LEARNING RESOURCES OF LITERATION TO DEVELOP A STUDENT CRITICAL THINKING ABILITY INSIDE THE DEVELOPMENT OF THE NATIONS
}

\author{
Nurchasanah \\ nurchasanah1959@gmail.com \\ Zakia Habsari \\ zakiahabsari23@gmail.com \\ (State University of Malang, Indonesia)
}

\begin{abstract}
In literacy learning, the text has multiple roles. Many teachers worry about text positions in literacy learning. The text acts as a learning medium if it works directly as a messenger of learning that makes students easier to learn. For that purpose, the text needs to be modified, manipulated, and given a special identity in accordance with the interests of learning. The text acts as a learning material if the text serves as an object learned in learning. In order for the text to serve as a learning material, the text needs to be identified, analyzed, and interpreted in accordance with the learning objectives. The text also serves as a learning resource if the text serves as the source of the content of the material learned in the study. For this purpose, the text reveals its original form without any changes and treatment. Regardless of the role of the text in learning, the text can function to develop students' critical thinking skills so they can welcome and play a role in nation building. In order for the text to have a role it can train students to think critically; the form, treatment, and function of the text need to be differentiated.
\end{abstract}

Keywords: text, media, material, learning resources, literacy, critical thinking.

\section{INTRODUCTION}

Philosophically, every interactive activity requires a means. Similarly, in learning literacy, learning tools are needed. The means that can directly channel the learning message is called instructional media. Learning media, especially literacy learning can be text. Through text, various knowledge of the world (word knowledge) can be obtained. Through text, knowledge of language and rhetoric can 
ISLLAC

Journal of Intensive Studies on Language, Literature, Art, and Culture

Vol. 1 No. 1 September 2017

be mastered. Therefore, the role of the text becomes important in learning, especially literacy learning.

In learning literacy, the effectiveness of learning activities is always a consideration. Effective learning will produce maximum results in a relatively short time. Suyono (2012) said that effective and productive learning is a learning that is planned to help students achieve two main goals, namely to achieve the goal of learning optimally and at the same time conditioned productive students in generating ideas. For that, needed media that can help achieve the effectiveness of learning, including learning media in the form of text.

Keep in mind that each student has different, differentiated initial capabilities. To help students who have below average skills, it is assumed that the use of instructional media is helpful. Teachers also have different competencies. To help facilitate the delivery of messages, the use of instructional media is assumed to be the right step. Includes the use of text media.

Through text, various literacy learning competencies can be obtained, including the competence of critical thinking. Critical thinking in literacy learning, especially reading, according to Priyatni (2011) is characterized by the ability to analyze and evaluate and demand readers to give judgments on the quality of content and style of text read based on criteria that can be accounted for. Such abilities are expected to be mastered by students so that they can solve complex life problems they face so they can play a role in nation building.

The ability to think critically can also be obtained through writing learning (Nurchasanah, 2015) by utilizing text media. Through writing learning, students try to think critically about finding ideas, developing ideas, organizing ideas systematically, and developing organized ideas with appropriate language in the form of written text.

The role of the text becomes a conversation among education. In the design of classroom learning, the text is often positioned as a learning material. Some are positioning the text as a learning resource. In fact, sometimes the text plays a role as a learning medium. If examined, the text can actually play a double role, can be positioned as media, materials, and learning resources. However, the treatment given to the text must be differentiated in order to function as intended. To that end, in this paper revealed the role of text in learning and treatment given to the text. To get an idea of it, some of the issues that need to be expressed in this paper are (1) text, (2) literacy, (3) text as a medium of literacy learning, (4) text as literacy learning materials, (5) text as learning resources literacy, (6) text as a means of developing critical thinking skills in literacy learning, and (7) the role of critical thinking in nation 
ISLLAC

Journal of Intensive Studies on Language, Literature, Art, and Culture

Vol. 1 No. 1 September 2017

building. These issues need to be presented in the hope of increasing the teacher's insight into positioning the text in the lesson so that they can give the correct treatment of the text to the text function as expected.

\section{TEXT}

The text means 'written materials or texts for lessons or speeches' (Language Center, 2003). Based on the meaning of the word, the text form of a written manuscript in various forms. Text can be in the form of articles, papers, research reports, thesis/dissertation, novels, short stories, drama script, poetry, news, reviews, biography, advertisements, news, The various forms of the text have different characteristics, content, language, and even the method of exposure. The concept of the text is now not limited to the written text as the Language Center says, but the whole oral statement is also called text as stated by Priyatni (2011).

Judging from the variety, the text is classified into two categories, namely, scientific texts and non-scientific texts. Both have different characteristics seen from the method of exposure and its object (Nurchasanah dan Lestari, 2013). Scientific texts present facts written following scientific methodologies and rules, whether related to content or language; while non-scientific texts present facts or nonfacts which are followed by the author's emotional elements.

The concept of text is identical to the concept of discourse. Discourse are functional units of discourse. Formally, the functional units of discourse from the linguistic units under the discourse, in the form of sentences, clauses, phrases, words, and letters/phonemes. Cook (1989) states that functionally, functional units forming oral discourse in the form of (1) system language: pronunciation, grammar, and vocabulary; (2) paralinguistic: voice, phase, and body; (3) knowledge: the cultural world; and (4) reasoning. Meanwhile, functional units of written discourse are (1) the language system: grammar and vocabulary; (2) paralinguistic: images, graphics, and so on; (3) knowledge: the cultural world; and (4) reasoning. Thus, it can be concluded that the text is a unit of functional units in the form of (1) system language: vocabulary and grammar, (2) paralinguistic: images, graphs, etc., (3) knowledge: the world of culture, and (4) form a whole statement.

\section{LITERATION}

\section{Literacy Concepts}

Initially, literacy has a range of areas related to reading and writing (Hornby, 2000). Meanwhile, Eanest (1997) says that literacy relates to reading-writing-thinking. In line with the development of science and technology, the literacy review area 
ISLLAC

Journal of Intensive Studies on Language, Literature, Art, and Culture

Vol. 1 No. 1 September 2017

reaches a wide range of activities. In fact, the term literacy has a changed sense of "information skills" as Usaid Priority (2014) says. The skill has a range of areas related to information seeking skills, information processing, organizing information, and using information. Finding information can be done by reading, listening, accessing information online, and so forth. The results of the activities were processed then organized and utilized for various purposes through oral and written language. Kern (2000) defines the term literacy comprehensively as the use of social and historical practices and cultural practices in creating and interpreting meaning through text. In this paper, the term literacy is limited to literary literature (readwrite-thinking).

\section{Literacy Learning}

Literacy learning is a teaching-learning activity that aims to make students learn in the literature. Learning literacy is directed at the business so that students want to learn alone in the literacy so that students can achieve learning objectives effectively. In order for learning objectives to be achieved effectively, literacy learning needs to be done continuously as Cropper (2001) has said, both inside and outside the classroom.

Related to the effectiveness of learning, Suyono (2012) in Nurchasanah (2015) said that effective and productive learning is a learning that is planned to help students achieve two main objectives, namely to achieve optimal learning objectives and simultaneously condition productive students in generating ideas.

\section{TEXT AS A LITERACY LEARNING MEDIA}

\section{Understanding Media Literacy Learning}

The term media is derived from Latin, is a plural of "medium" which means 'mediator' or 'introduction'. Thus, the media has a sense of everything that can channel information from sources informants to the recipient of information (Mustikasari, 2008).

As quoted by Sudrajad (2008), Schramm said that learning media is a messenger technology that is utilized for learning purposes. Briggs said that learning media is a physical means to deliver learning content, such as books, films, videos, etc. Meanwhile, the National Education Association suggests that learning media is a means of communication in the form of print and hearing, including hardware technology. Based on the above three opinions, Sudrajad (2008) concluded that the learning media is anything that can channel the message, can stimulate the mind, 
ISLLAC

Journal of Intensive Studies on Language, Literature, Art, and Culture

Vol. 1 No. 1 September 2017

feelings, and willingness of learners so as to encourage the creation of learning process in learners themselves.

By adhering to these notions, literacy learning media is the means of messengers used by teachers and students in learning literacy. Text can be considered as printed media. Text can deliver messages to students. For messages to be easily understood, texts need to be engineered for the purpose of learning to be achieved effectively and efficiently.

\section{Learning Media Literacy Function}

Learning media has the function as a presenter and channel message. In certain cases, the media can represent teachers in presenting learning information to students. If the media is designed and well developed, the functionality can be played by the media even without the teacher's presence. In general, the benefits of learning media is to facilitate the interaction between teachers and students so that learning activities more effective and efficient. In particular, the benefits of learning media are (1) the delivery of learning materials can be uniformed, (2) the learning process more clear and interesting, (3) the learning process more interactive, (4) more efficient time and energy, (5) improve the quality of learning outcomes , (6) enabling the learning process to be done anywhere and anytime, (7) cultivating students' positive attitudes toward learning materials and processes, and (8) changing the role of teachers towards positive and productive (Mustikasari, 2008).

Sudrajad (2008) says that learning media has the function of (1) can overcome the limitations of the learner's experience, (2) can exceed the classroom boundary, (3) enabling direct interaction between learners and the environment, (4) result in uniformity of observation, (5) inculcate the basic concepts that are true, concrete, and realistic, (6) generate new desires and interests, (7) generate motivation and stimulate children to learn, and (8) provide an integral / comprehensive experience from the concrete to the abstract.

\section{The Role of Text as Literacy Learning Media}

As has been said above that the text can play a role in learning. One of the roles of text is a medium of literacy learning. In order for the text to act as a medium of literacy learning, the text needs to be engineered by modifying, manipulated, and given a special identity in accordance with the interests of learning. This modification is required in the hope that the function of text as a medium that facilitates students in learning as said Mustikasari (2008) and Sudrajad (2008) are met. 
ISLLAC

Journal of Intensive Studies on Language, Literature, Art, and Culture

Vol. 1 No. 1 September 2017

For example, if the goal of learning is to instill a "textual understanding of the elements and structure of the text" to the student, the text needs to be given a specific identity for each element of the structure so that students can easily understand it, as exemplified by Nurchasanah (2014) below.

\begin{tabular}{|c|c|}
\hline $\begin{array}{c}\text { PERLU PENYUSUNAN RUU PENGASUHAN } \\
\text { ANAK } \\
\text { Komisi VIII DPR Terbuka pada Usulan Pemerintah } \\
\text { dan Masyarakat }\end{array}$ & Title and Child Title \\
\hline JAKARTA, KOMPAS & $\begin{array}{l}\text { Deadline: the scene } \\
\text { and the name of the } \\
\text { media }\end{array}$ \\
\hline $\begin{array}{l}\text { Rancangan Undang-Undang Pengasuhan Anak tengah } \\
\text { disiapkan dan didorong untuk menjadi inisiatif DPR. } \\
\text { Keseluruhan bentuk pengasuhan anak direncanakan } \\
\text { diatur di dalam Undang-undang yang memberi ruang } \\
\text { bagi kehadiran negara di dalam keluarga itu. }\end{array}$ & $\begin{array}{l}\text { News Terrace (Lead): } \\
\text { Digest of news }\end{array}$ \\
\hline $\begin{array}{l}\text { Deputi Perlindungan Anak Kementerian Pemberdayaan } \\
\text { Perempuan dan Perlindungan Anak (KPPPA), Pribudiarta } \\
\text { Nur Sitepu, Minggu (28/8), di Jakarta, menyampaikan } \\
\text { penilaiannya bahwa dengan menjadi inisiatif DPR, RUU } \\
\text { Pengasuhan Anak akan lebih cepat disahkan. Karena itu, } \\
\text { menurut dia, masyarakat sipil melalui lembaga swadaya } \\
\text { masyarakat beserta organisasi-organisasi keagamaan } \\
\text { melakukan lobi kepada Komisi VIII DPR. } \\
\text { Adapun materi RUU Pengasuhan Anak yang sejauh ini } \\
\text { mencakup } 177 \text { pasal diolah oleh KPPPA, Kementerian } \\
\text { Sosial. Ada pula wakil dari masyarakat yang dilibatkan dalam } \\
\text { penyusunannya. }\end{array}$ & $\begin{array}{l}\text { Body News (Body): } \\
\text { Content informed news }\end{array}$ \\
\hline
\end{tabular}


ISLLAC

Journal of Intensive Studies on Language, Literature, Art, and Culture

Vol. 1 No. 1 September 2017

\begin{tabular}{|l|l|}
\hline $\begin{array}{l}\text { dibuat karena selama ini dinilai belum ada sistematisasi } \\
\text { pengasuhan anak di keluarga. UU Perlindungan Anak hanya } \\
\text { mengatur pengasuhan anak di lembaga-lembaga sosial. }\end{array}$ & \\
$\ldots$ & \\
$\ldots$ & \\
\hline $\begin{array}{l}\text { Menurut Ledia, penyusunan RUU Pengasuhan Anak } \\
\text { harus dilakukan dengan cermat agar tidak bentrok } \\
\text { dengan UU Perlindungan Anak . "Bisa saja, topik } \\
\text { pengasuhan anak dimasukkan sebagai perubahan atas UU } \\
\text { Perlindungan Anak. Bahkan, kalau perbaikannya lebih dari } \\
50 \text { persen bisa dipertimbangkan sebagai perubahan total UU } \\
\text { Perlindungan Anak," ujarnya. (DNE) }\end{array}$ & initials \\
Source: Modified, Compass, Monday, August 20, 2016 &
\end{tabular}

To facilitate students' understanding (in accordance with the function of the media), the engineered text can also be colored for each element, for example the title is colored red to be conspicuous so that it gets more attention from students, deadlines are given green, the terrace is blue, the body is black, and the cover is yellow. In fact, the text can be modified in the language if the text is used as an expected model is exemplary. In fact, text can be packed using IT-based media.

\section{TEXT AS LITERATURE LEARNING MATERIAL}

\section{Understanding Literacy Learning Materials}

Aside from being a learning medium, texts can serve as learning materials. Learning materials are all the knowledge, skills, and attitudes that students must learn in order to achieve their competencies (MoNE, 2006). Material knowledge can be facts, concepts, principles, and procedures. Skill material in the form of application of knowledge in certain practice activities in accordance with the purpose of learning. The material attitude in the form of ideal behavior that usually associated with the expected character appears in certain learning practices, such as discipline, responsibility, polite, and so forth. 
ISLLAC

Journal of Intensive Studies on Language, Literature, Art, and Culture

Vol. 1 No. 1 September 2017

\section{Principles of Development of Literacy Learning Materials}

To develop learning materials (teaching materials), there are several principles that need to be followed, namely relevance, consistency, and adequacy. Relevant teaching materials mean teaching materials developed in accordance with the Competency Standards and Basic Competencies specified Curriculum applicable. Teaching materials that have consistency mean that the material is in accordance with the purpose of achieving competence. Meanwhile, teaching materials that meet the principle of sufficiency mean the material in quality and quantity is sufficient (MoNE, 2006). Other things to consider in the development of teaching materials are (1) accuracy: theoretical material truth and (2) the relevance of the material to the development of students' cognitions, interests, and environmental context.

\section{The Role of Text as Literacy Learning Material}

As it is said that learning materials are all knowledge, skills, and attitudes that must be learned by students so that they can achieve the competencies specified (MoNE, 2006). Knowledge materials related to "news text" can be learned through text examples, starting from facts, concepts, principles, and procedures. Skill material can be knowledge application in making the news. Material attitude can be an attitude of discipline, responsibility, and honest in making the news. The texts played as teaching materials must be accompanied by the results of identification, analysis, interpretation, and so forth related to the news text, as exemplified below.

\begin{tabular}{|c|c|}
\hline MATERIALS AJAR & \multicolumn{1}{|c|}{ MATERIAL DEVICE } \\
(Examples Modified) & TITLE \\
$\begin{array}{c}\text { PERLU PENYUSUNAN RUU } \\
\text { PENGASUHAN ANAK }\end{array}$ & Knowledge Material: \\
$\begin{array}{c}\text { Komisi VIII DPR Terbuka pada } \\
\text { Usulan Pemerintah dan Masyarakat }\end{array}$ & $\begin{array}{l}\text { 2. Sefinition of Title (Concept) } \\
\text { 3. Principle Formulation Principles } \\
\text { (Principles) }\end{array}$ \\
& $\begin{array}{c}\text { 4. Title Making Techniques } \\
\text { (Procedures) }\end{array}$ \\
\hline
\end{tabular}


ISLLAC

Journal of Intensive Studies on Language, Literature, Art, and Culture

Vol. 1 No. 1 September 2017

\begin{tabular}{|c|c|}
\hline & $\begin{array}{l}\text { Material Skills: } \\
\text { 1. Define Title Content } \\
\text { 2. Formulate the Title Contents } \\
\text { with } \\
\text { Correct Languages and Spellings } \\
\text { 3. Example of Content Title and } \\
\text { Formulation }\end{array}$ \\
\hline JAKARTA, KOMPAS & $\begin{array}{l}\text { DEADLINE } \\
\text { Knowledge Material: } \\
\text { 1. Deadline Example } \\
\text { 2. Understanding Deadline } \\
\text { 3. Deadline Content Principle } \\
\text { 4. Technique to Make Deadline } \\
\text { Material Skills: } \\
\text { 1. Define Deadline Content } \\
\text { 2. Prepare Deadline Content } \\
\text { 3. Example of Content Deadline } \\
\text { and its } \\
\text { Composition }\end{array}$ \\
\hline $\begin{array}{l}\text { Rancangan Undang-Undang Pengasuhan } \\
\text { Anak tengah disiapkan dan didorong untuk } \\
\text { menjadi inisiatif DPR. Keseluruhan bentuk } \\
\text { pengasuhan anak direncanakan diatur di } \\
\text { dalam Undang-undang yang memberi ruang } \\
\text { bagi kehadiran negara di dalam keluarga itu. }\end{array}$ & $\begin{array}{l}\text { NEWS TERRACE (LEAD) } \\
\text { Knowledge Material: } \\
\text { 1. Example of News Terrace } \\
\text { 2. Definition of News Terrace } \\
\text { 3. The Preparation Principles of the } \\
\text { News Terrace } \\
\text { 4. Technique of Making Terrace }\end{array}$ \\
\hline
\end{tabular}


ISLLAC

Journal of Intensive Studies on Language, Literature, Art, and Culture

Vol. 1 No. 1 September 2017

\begin{tabular}{|c|c|}
\hline & $\begin{array}{l}\text { News } \\
\text { Material Skills: } \\
\text { 1. Determine the content of the } \\
\text { news } \\
\text { terrace } \\
\text { 2. Develop the content of the } \\
\text { news } \\
\text { terrace with the appropriate } \\
\text { language } \\
\text { 3. Example of the Contents of the } \\
\text { News Terrace and the Form of } \\
\text { the Developed News Terrace }\end{array}$ \\
\hline $\begin{array}{l}\text { Deputi Perlindungan } \\
\text { Kementerian Pemberdayaan Perempuan } \\
\text { dan Perlindungan Anak (KPPPA), } \\
\text { Pribudiarta Nur Sitepu, Minggu (28/8), di } \\
\text { Jakarta, menyampaikan penilaiannya bahwa } \\
\text { dengan menjadi inisiatif DPR, RUU } \\
\text { Pengasuhan Anak akan lebih cepat } \\
\text { disahkan. Karena itu, menurut dia, } \\
\text { masyarakat sipil melalui lembaga swadaya } \\
\text { masyarakat beserta organisasi-organisasi } \\
\text { keagamaan melakukan lobi kepada Komisi } \\
\text { VIII DPR. } \\
\text { Adapun materi RUU Pengasuhan } \\
\text { Anak yang sejauh ini mencakup 177 pasal } \\
\text { diolah oleh KPPPA, Kementerian Sosial. } \\
\text { Ada pula wakil dari masyarakat yang } \\
\text { dilibatkan dalam penyusunannya. } \\
\text { Pribudiarta menjelaskan, } \\
\text { Pengasuhan Anak dibuat karena selama ini } \\
\text { dinilai belum ada sistematisasi pengasuhan } \\
\text { anak di keluarga. UU Perlindungan Anak } \\
\text { hanya mengatur pengasuhan anak di }\end{array}$ & $\begin{array}{l}\text { BODY NEWS (BODY) } \\
\text { Knowledge Material: } \\
\text { 1. Example Body News } \\
\text { 2. Understanding Body News } \\
\text { 3. The Preparation Principles of Body } \\
\quad \text { News } \\
\text { 4. Technique Make Body News } \\
\text { Material Skills: } \\
\text { 1. Determining Body Content News } \\
\text { 2. Sort Body Content News } \\
\text { 3. Developing News Content that has } \\
\text { been Sorted in the Form of } \\
\text { Paragraphs with the Right Language } \\
\text { 4. Checking for Cohesion and } \\
\text { Coherence of Interagagraphs }\end{array}$ \\
\hline
\end{tabular}


ISLLAC

Journal of Intensive Studies on Language, Literature, Art, and Culture

Vol. 1 No. 1 September 2017

\begin{tabular}{|c|c|}
\hline lembaga-lembaga sosial. & $\begin{array}{l}\text { 5. Sample Content, Sequence of Content, } \\
\text { Existence of Developed Body, } \\
\text { Cohesion and Body Coherence of } \\
\text { News }\end{array}$ \\
\hline $\begin{array}{l}\text { Menurut Ledia, penyusunan RUU } \\
\text { Pengasuhan Anak harus dilakukan dengan } \\
\text { cermat agar tidak bentrok dengan UU } \\
\text { Perlindungan Anak. "Bisa saja, topik } \\
\text { pengasuhan anak dimasukkan sebagai } \\
\text { perubahan atas UU Perlindungan Anak. } \\
\text { Bahkan, kalau perbaikannya lebih dari } 50 \\
\text { persen bisa dipertimbangkan sebagai } \\
\text { perubahan total UU Perlindungan Anak," } \\
\text { ujarnya. (DNE) }\end{array}$ & $\begin{array}{l}\text { Knowledge Material: } \\
\text { 1. Sample Closing News } \\
\text { 2. Definition of News Closing } \\
\text { 3. The Principle of Closing the } \\
\quad \text { News } \\
\text { 4. Technique Making News Closing } \\
\text { Material Skills: } \\
\text { 1. Determine the content of the } \\
\text { news } \\
\text { cover } \\
\text { 2. Develop closing content with } \\
\text { appropriate language } \\
\text { 3. Examples of closing content } \\
\text { and the form of news coverage } \\
\text { that has been developed }\end{array}$ \\
\hline \multicolumn{2}{|c|}{$\begin{array}{l}\text { Note: } \\
\text { (1) Material attitude can be confidence, responsibility, and honest. (2) Each material } \\
\text { content needs to be described and explained in detail by reference to the example } \\
\text { news text. } \\
\text { (3) Through text examples, students are directed to practice writing news with } \\
\text { content, structure, and the correct language so that they are skilled at writing the } \\
\text { news. }\end{array}$} \\
\hline
\end{tabular}


ISLLAC

Journal of Intensive Studies on Language, Literature, Art, and Culture

Vol. 1 No. 1 September 2017

(4) Through learning to examine and write news texts, confidence, discipline, and honest

will grow as well as their creativity develops.

(5) Aspects of knowledge, skills, and attitudes need to be defined in the formulation indicators of learning competence.

\section{TEXT AS A LEARNING RESOURCES OF LITERATION}

\section{Understanding Learning Resources Literacy Learning}

Learning resources are tools that can be utilized to gain knowledge in learning. Learning resources can be (1) printed materials, such as text-shaped books, magazines, journals, newspapers, and so on; (2) information from electronic means, such as video, TV, and radio; (3) human beings, such as certain field experts; etc. In this context, the source of learning in the form of text because the text contains various information knowledge of the world (world knowledge) that students learn. Text can be obtained from various learning sources, such as news text obtained from newspapers or magazines. Thus, it can be said that the text in the learning of literacy is a source of direct learning that contains various knowledge of the world that students use in learning literacy.

\section{The Role of Text as a Learning Literacy Learning Source}

Learning resources can be text that reveals the original form. This text does not need to be modified. The goal is to know the original source so that it can be known also naturality texts referenced. The text form as a learning resource is exemplified below.

\section{DISUSUN RUU PENGASUHAN ANAK}

\section{Komisi VIII DPR Terbuka pada Usulan Pemerintah dan Masyarakat}

JAKARTA. KOMPAS - Rancangan Undang-Undang Pengasuhan Anak tengah disiapkan dan didorong untuk menjadi inisiatif DPR. Keseluruhan bentuk pengasuhan anak direncanakan diatur di dalam Undang-undang yang memberi ruang bagi kehadiran Negara di dalam keluarga itu. 
ISLLAC

Journal of Intensive Studies on Language, Literature, Art, and Culture

Vol. 1 No. 1 September 2017

Deputi Perlindungan Anak Kementerian Pemberdayaan Perempuan dan Perlindungan Anak (KPPPA) Pribudiarta Nur Sitepu, Minggu (28/8), di Jakarta, menyampaikan penilaiannya bahwa dengan menjadi inisiatif DPR, RUU Pengasuhan Anak akan lebih cepat disahkan. Karena itu menurut dia, masyarakat sipil melalui lembaga swadaya masyarakat beserta organisasi-organisasi keagamaan melakukan lobi kepada Komisi VIII DPR.

Adapun materi RUU Pengasuhan Anak yang sejauh ini mencakup 177 pasal diolah oleh KPPPA, Kementerian Sosial. Ada pula wakil dari masyarakat yang dilibatkan dalam penyusunannya.

Pribudiarta menjelaskan, RUU Pengasuhan Anak dibuat karena selama ini dinilai belum ada sistematisasi pengasuhan anak di keluarga. UU Perlindungan Anak hanya mengatur pengasuhan anak di lembaga-lembaga sosial.

$\cdots$

Menurut Ledia, penyusunan RUU Pengasuhan Anak harus dilakukan dengan cermat agar tidak bentrok dengan UU Perlindungan Anak . "Bisa saja, topik pengasuhan anak dimasukkan sebagai perubahan atas UU Perlindungan Anak. Bahkan kalau perbaikannya lebih dari 50 persen bisa dipertimbangkan sebagai perubahan total UU Perlindungan Anak," ujarnya. (DNE)

Source: Kompas, Monday, August 20, 2016

\section{TEXT AS THE DEVELOPMENT OF CRITICAL THINKING ABILITY IN LEARNING LITERATION}

\section{The Concept of Critical Thinking in Literacy Learning}

As explained by Eanest (1997) that the literary review area includes reading, writing, and thinking. Thinking activities are integrated with reading and writing activities. Nurchasanah (2016a) says that any language learning activities, including reading and writing, require thinking. Thinking has a gradation of difficulty. In literacy reading activities, Nurhadi (2009) and Nurchasanah (2014) say that thinking has three levels, namely literal thinking, critical thinking, and creative thinking. Further explained by Nurchasanah (2014) that literal thinking is characterized by the behavior of identifying readings and recalling aspects of reading. Critical thinking is characterized by reorganizing behavior (classifying, framing, summarizing, synthesizing), inferencing, evaluating and appreciating. The behavior of creative 
ISLLAC

Journal of Intensive Studies on Language, Literature, Art, and Culture

Vol. 1 No. 1 September 2017

thinking is shown by the following behaviors: the ability to practice read instructions, change post-reading attitudes, make things based on readable theories and examples, convert articles, correct text errors, and so on. In order for the text to facilitate students in critical thinking necessary exercises that require critical thinking in relation to the text being read. The ability to think it can be grown and developed among them through the learning of literacy as said by Nurchasanah (2016a).

\section{Critical Thinking in Reading Learning}

Reading is an activity of perceiving written text or reading (Nurchasanah, 2016b). In reading learning, reading comprehension becomes the key to reading. Text can work to develop students' understanding and critical thinking. Quoting the views of some experts, Priyatni (2011) says that critical reading is a reading activity that involves the process of analysis and evaluation and requires the reader to give judgments on the quality of the content and the style of the text read according to the criteria that can be accounted for. Kurland (2000) and Nurhadi (2009) suggest that a critical understanding of reading is a higher level of understanding than literal understanding. In order for the text to train students' critical thinking skills, the given training needs to consider the level of critical thinking. Exercise that can be given can be (1) answer critical questions, (2) perform tasks that demand critical thinking, and (2) make critical questions.

Examples of activities that demand critical thinking and its classification in reading are described below.

\section{Read the following text carefully!}

\section{PERLU PENYUSUNAN RUU PENGASUHAN ANAK}

\section{Komisi VIII DPR Terbuka pada Usulan Pemerintah dan Masyarakat}

JAKARTA, KOMPAS - Rancangan Undang-Undang Pengasuhan Anak tengah disiapkan dan didorong untuk menjadi inisiatif DPR. Keseluruhan bentuk pengasuhan anak direncanakan diatur di dalam Undang-undang yang memberi ruang bagi kehadiran negara di dalam keluarga itu. 
ISLLAC

Journal of Intensive Studies on Language, Literature, Art, and Culture

Vol. 1 No. 1 September 2017

Deputi Perlindungan Anak Kementerian Pemberdayaan Perempuan dan Perlindungan Anak (KPPPA), Pribudiarta Nur Sitepu, Minggu (28/8), di Jakarta, menyampaikan penilaiannya bahwa dengan menjadi inisiatif DPR, RUU Pengasuhan Anak akan lebih cepat disahkan. Karena itu, menurut dia, masyarakat sipil melalui lembaga swadaya masyarakat beserta organisasi-organisasi keagamaan melakukan lobi kepada Komisi VIII DPR.

Adapun materi RUU Pengasuhan Anak yang sejauh ini mencakup 177 pasal diolah oleh KPPPA, Kementerian Sosial. Ada pula wakil dari masyarakat yang dilibatkan dalam penyusunannya.

Pribudiarta menjelaskan, RUU Pengasuhan Anak dibuat karena selama ini dinilai belum ada sistematisasi pengasuhan anak di keluarga. UU Perlindungan Anak hanya mengatur pengasuhan anak di lembaga-lembaga sosial.

Menurut Ledia, penyusunan RUU Pengasuhan Anak harus dilakukan dengan cermat agar tidak bentrok dengan UU Perlindungan Anak . "Bisa saja, topik pengasuhan anak dimasukkan sebagai perubahan atas UU Perlindungan Anak. Bahkan, kalau perbaikannya lebih dari 50 persen bisa dipertimbangkan sebagai perubahan total UU Perlindungan Anak," ujarnya. (DNE)

Sumber: Modifikasi, Kompas, Senin, 20 Agustus 2016

After you read the text above, answer the following questions! 
ISLLAC

Journal of Intensive Studies on Language, Literature, Art, and Culture

Vol. 1 No. 1 September 2017

\section{Reorganize}

1. Group, which statements are classified as facts and which are classified as opinions! Write in the following table!

\begin{tabular}{|l|l|}
\hline Facts & Opinion \\
\hline & \\
\hline & \\
\hline
\end{tabular}

2. Create a skeleton of the news that you just read in phrases and sentences!

3. Make a summary of the news content you just read by considering the content and

\section{Language content!}

4. How is the suitability of the headline that you just read with the contents and the organization?

\section{Referring}

1. What consequences will happen if the Child Protection Act is not immediately prepared?

2. Explain the focus of news coverage you read!

3. What values can you pick after reading the news?

\section{Evaluate}

1. According to your judgment, how is the language of the news you read?

2. According to your judgment, how is the content of the news you read?

\section{Appreciate}


ISLLAC

Journal of Intensive Studies on Language, Literature, Art, and Culture

Vol. 1 No. 1 September 2017

1. What do you feel after the initiative to rebuild the Child Protection Act by the House of

Representatives?

2. How would your attitude be if the Child Protection Act was changed?

\section{Critical Thinking in Writing Learning}

Writing is an act of producing written language. Write is active. Writing activity indicates that writing activity requires thinking (Nurchasanah, 2016b). Nurchasanah and Widodo (1993) say that writing is an activity expressing ideas, feelings, and will by using written language in accordance with the rules that apply. In writing activities, critical thinking is required. Critical thinking activities in writing are seen in skills (1) finding ideas with reasons, (2) determining the scope of ideas, (3) organizing ideas found, (3) developing organized ideas with proper writing and spelling.

In finding ideas, students are required to seek ideas, compare ideas to one another, consider possibilities, whether they can be developed in writing, and decide 115 
ISLLAC

Journal of Intensive Studies on Language, Literature, Art, and Culture

Vol. 1 No. 1 September 2017

on ideas to be developed. In determining the scope of the content of ideas, the author must learn theories as for the basis for determining the content area of the study. The content area of the study needs to be organized to make it easier to organize the order of ideas to be systematic. The ideas that have been systematically sorted are further developed using appropriate language, correct spelling, correct cohesion, and coherence.

\section{THE ROLE OF CRITICAL THINKING IN THE DEVELOPMENT OF THE NATIONS}

Humans basically have special abilities, namely analytic ability and synthetic ability as Herbart (Siswanto, 2017). The analytic and synthetic abilities of humans show that they are basically having the provision to think critically. Siswanto (2017) added that the capabilities will develop in the educational process. The ability that makes people have the awareness of thinking to free themselves from all the limitations faced and escape from the various dependence of life in order to live independently and responsible as a human being.

Nurchasanah (2016a) says that critical thinking needs to be instilled into the students through continuous reading and writing so that they are productively creative in the literacy (Nurchasanah, 2016a). In fact, Cropper (2001) says that the activity is not only trained continuously but needs to be trained inside or outside the classroom. Thus, the basic capabilities that humans possess as stated by Herbart can develop maximally.

This is in line with Siswanto's (2017) statement that critical thinking should continue to be developed in every generation through the educational process as an absolute not only to criticize modernization but also to keep the development of civilization of humanity, nation, and state in a better direction.

With the provision of critical thinking skills, they are believed to solve complex problems in today's global era. This behavior is certainly a capital in facing the development of human resources that will impact on nation building.

\section{CONCLUSION}

In literacy learning, text can play a role: as media, material, and learning resources, depending on the function of the text in learning. Regardless of the role, 
ISLLAC

Journal of Intensive Studies on Language, Literature, Art, and Culture

Vol. 1 No. 1 September 2017

the text can serve to train students to develop critical thinking skills. Armed with the ability to think critically, students are expected to welcome and play a role in nation building. In order for the text to have a role it can train students to think critically; the form and treatment of the text need to be differentiated so that the text has the proper function as expected.

\section{REFERENCES}

Cook, G. (1989). Discourse. New York: Oxford University Press.

Cropper, E. (2001). Secondary Literacy Success, Literacy Issues, and Database. (Online).rtrieved from http://www.literacytrust. org.uk/Database/myrtle.html, accessed May 11, 2004.

Depdiknas. (2006). Pedoman Memilih dan Menyusun Bahan Ajar. Jakarta: Departemen Pendidikan Nasional.

Earnest, R. (19970. Content Area Literacy: Teaching for Today and Tomorrow. Washington: ITP An International Thomson Publishing Company.

Hornby, AS. (2000). Oxford Advanced Learner's Dictionary of Current English. UK: Oxford University Press.

Kern. R. (2000). Literacy and Language Teaching. Oxford: Oxford University Press.

Kurland, D. J. and Kurland's. (2000). What is Critical Reading? (Online). Retrieved on February 12, 2009from www.criticalreading.com.

Mustikasari, A. (2008). Mengenal Media Pembelajaran (Online). Retrieved on December 9, 2009, from http://edu-articles.com.

Nurchasanah. (2015). Pembelajaran Literasi di Perguruan Tinggi. Paper presented at Senabastra VII National Seminar in Unijoyo, Madura, June 10, 2015.

Nurchasanah. (2016a). Berpikir Analitis, Praktis, dan Kreatif dalam Pembelajaran Literasi. The article is presented in the National Seminar of Nitisastra, Postgraduate UM, May 21, 2016

Nurchasanah. (2016b). Indonesian for Scientific Purposes Learning Based on Literacy with Individuals, Groups, and Classicals Learning Integration. Articles are presented at the LSCAC International Seminar, UM, May 24-25, 2016.

Nurchasanah \& Lestari. (2013). Dasar-dasar Menulis Karya Ilmiah. Malang: Aditya Media Publishing.

Nurchasanah \& Widodo. (1993). Keterampilan Menulis dan Pengajarannya. Malang: Proyek Operasi dan Perawatan Fasilitas IKIP Malang.

Nurhadi. (2009). Dasar-dasar Teori Membaca. Malang: Universitas Negeri Malang. 
ISLLAC

Journal of Intensive Studies on Language, Literature, Art, and Culture

Vol. 1 No. 1 September 2017

Priyatni, E.T. (2011). Membaca Kritis: Berbasis Intervensi dengan Multimedia. The dissertation product is not published. Malang: Postgraduate MU

Pusat Bahasa. (2003). Kamus Pelajar. Jakarta: Pusat Bahasa.

Siswanto. (2017). Absolute Critical Thinking in Indonesian Education (Online). Retrieved 5 September 2017. from http://asiswanto.net/?page_id=337.

Sudrajat, A. 2008. Media Pembelajara (Online). http://akhmadsudrajad.com. .

Suyono. (2012). Effective and Productive Learning Based Literacy: Analysis of Context, Principles, and Alternative Behavior of Implementation Strategy at Campus (Online). Retrieved 12 January 2014 from http://sastra.um.ac.id/wpcontent/uploads/2012/01/9- Suyono.docx.pdf.

Usaid Priority. (2014). Good Practice in Junior High School/Madrasah Tsanawiyah. RTI International, EDC Learning Transforms Lives, Word Education. 